\title{
Three-day dendritic cells for vaccine development: Antigen uptake, processing and presentation
}

\author{
Maja Bürdek, Stefani Spranger, Susanne Wilde, Bernhard Frankenberger, Dolores J Schendel", Christiane Geiger
}

\begin{abstract}
Background: Antigen-loaded dendritic cells (DC) are capable of priming naïve T cells and therefore represent an attractive adjuvant for vaccine development in anti-tumor immunotherapy. Numerous protocols have been described to date using different maturation cocktails and time periods for the induction of mature DC (mDC) in vitro. For clinical application, the use of $\mathrm{mDC}$ that can be generated in only three days saves on the costs of cytokines needed for large scale vaccine cell production and provides a method to produce cells within a standard work-week schedule in a GMP facility.
\end{abstract}

Methods: In this study, we addressed the properties of antigen uptake, processing and presentation by monocytederived $\mathrm{DC}$ prepared in three days (3d mDC) compared with conventional $\mathrm{DC}$ prepared in seven days ( $7 \mathrm{~d} \mathrm{mDC}$ ), which represent the most common form of DC used for vaccines to date.

Results: Although they showed a reduced capacity for spontaneous antigen uptake, $3 \mathrm{~d} \mathrm{mDC}$ displayed higher capacity for stimulation of $\mathrm{T}$ cells after loading with an extended synthetic peptide that requires processing for MHC binding, indicating they were more efficient at antigen processing than $7 \mathrm{~d} D C$. We found, however, that $3 \mathrm{~d}$ DC were less efficient at expressing protein after introduction of in vitro transcribed (ivt)RNA by electroporation, based on published procedures. This deficit was overcome by altering electroporation parameters, which led to improved protein expression and capacity for T cell stimulation using low amounts of ivtRNA.

Conclusions: This new procedure allows $3 \mathrm{~d} \mathrm{mDC}$ to replace $7 \mathrm{~d} \mathrm{mDC}$ for use in $\mathrm{DC}$-based vaccines that utilize long peptides, proteins or ivtRNA as sources of specific antigen.

\section{Background}

The benefit of dendritic cells (DC) as adjuvants to induce tumor-specific cytotoxic $\mathrm{T}$ cells as well as helper $\mathrm{T}$ cells has been demonstrated in animal experiments and initial human trials [1,2]. In different tumor vaccines that were successfully applied in mice, mature DC $(\mathrm{mDC})$ were used that were loaded with tumor antigens, supplied in various forms, including tumor extracts, short peptides or antigen-encoding RNA [3,4]. Several clinical trials using DC as tumor-vaccines have also been performed, where an increased $\mathrm{T}$ cell response against tumor-associated antigens could be observed [5].

\footnotetext{
* Correspondence: schendel@helmholtz-muenchen.de
Helmholtz Zentrum München, German Research Center for Environmental

* Correspondence: schendel@helmholtz-muenchen.de
Helmholtz Zentrum München, German Research Center for Environmental Health, Institute of Molecular Immunology, Marchioninistr. 25, 81377 München, Germany
}

(C) 2010 Bürdek et al; licensee BioMed Central Ltd. This is an Open Access article distributed under the terms of the Creative Commons Attribution License (http://creativecommons.org/licenses/by/2.0), which permits unrestricted use, distribution, and reproduction in any medium, provided the original work is properly cited. the stimulation of naïve T cells [6]. Immature DC (iDC) patrol peripheral tissues and take up antigens via macropinocytosis, phagocytosis or receptor-mediated endocytosis. After uptake of antigen, iDC process and present antigen-derived peptides on their MHC molecules. Since DC have the ability for cross-presentation, exogenous antigens can be presented on MHC-II as well as on MHC-I molecules [7]. Presentation of antigens by iDC leads to $\mathrm{T}$ cell anergy, deletion of $\mathrm{T}$ cells or the induction of IL-10-secreting $\mathrm{T}$ regulatory cells $[8,9]$. Following antigen uptake, iDC convert to a mature phenotype, characterized by the upregulation of different cell surface molecules, such as CD40, CD80 and CD83 [10]. These $\mathrm{mDC}$ also show higher expression of the chemokine-receptor CCR7, which plays an important role for DC homing to lymph nodes [11]. Upon arrival in the 
lymph nodes, antigen-loaded $\mathrm{mDC}$ are able to prime naïve $\mathrm{T}$ cells, which then exit the lymph nodes after antigen-encounter. The primed effector $\mathrm{T}$ cells can recognize and eliminate specific target cells in the periphery.

Different protocols for the generation of DC have been described to date. In vitro, DC can be developed from $\mathrm{CD} 34^{+}$precursor cells or $\mathrm{CD} 14^{+}$monocytes $[10,12]$. Monocytes can be enriched from peripheral blood mononuclear cells (PBMC) via plate adherence, by the use of anti-CD14 antibodies or by elutriation of leukapheresis products. iDC are usually induced by stimulation with GM-CSF and IL-4 $[13,14]$. It has also been shown that IL-4 could be replaced by IL-15, leading to the differentiation of monocytes into cells with properties of Langerhans cells [15-17]. Furthermore, DC can also be induced in the presence of IFN- $\beta$ and IL-3 $[18,19]$. The induction of $\mathrm{mDC}$ can be initiated by several different stimuli, including microbial components (e.g. LPS as a Toll-like receptor 4 ligand), proinflammatory cytokines, viral-like stimuli [e.g. poly (I:C)] or T cell-derived molecules (e.g. CD40L) [16,18,20-24]. Depending on the composition of the maturation cocktails, mDC show different stimulatory and polarizing capacities on naïve $T$ cells.

Most protocols for the generation of $\mathrm{mDC}$ require approximately one week of cell culture. As such, Jonuleit and colleagues induced $\mathrm{mDC}$ on day five to six of a seven-day culture period by adding a four-component maturation cocktail (hereafter $4 \mathrm{C}$ cocktail), containing TNF- $\alpha$, IL-1 $\beta$, IL- 6 and PGE $_{2}$ [22], that is commonly used for the induction of DC maturation. It has been shown that $\mathrm{mDC}$ could also be generated within two days $[25,26]$. These "fast DC" were generally able to prime naïve $\mathrm{T}$ cells or stimulate effector cells $[25,27,28]$. The faster development of $\mathrm{mDC}$ may better reflect the situation in vivo [29].

In this study, we performed a systematic comparison of $3 \mathrm{~d}$ and $7 \mathrm{~d} \mathrm{mDC}$ in terms of phenotype, chemokinedirected migration, antigen uptake and subsequent stimulation of cytotoxic T lymphocytes (CTL) after incubation with exogenous peptides or loading with antigen via electroporation. Because different forms of antigen are considered for use in DC-based vaccine development, it was important to demonstrate that $\mathrm{mDC}$ prepared in a three-day protocol would have antigen processing capacity comparable to the well known properties of $7 \mathrm{~d} \mathrm{mDC}$.

\section{Materials and methods}

\section{Peptides, antibodies and reagents}

The short MART-1/Melan- $\mathrm{A}_{26-35}$ peptide (ELAGIGILTV) (purchased from Metabion, Martinsried, Germany) and the long MART-1/Melan-A peptide
(GSGHWDFAWPWGSGLAGIGILTV) (purchased from Biosyntan, Berlin, Germany) were reconstituted in 50\% DMSO containing water at a concentration of $1 \mathrm{mg} / \mathrm{ml}$ and $20 \mathrm{mg} / \mathrm{ml}$, respectively. Further dilutions were performed in medium. Monoclonal antibodies specific for DC surface molecules were directly labelled and purchased from Becton Dickinson (Heidelberg, Germany). The unlabelled CCR7 (clone 2H4) antibody (Becton Dickinson) and the MART-1/Melan-A antibody (clone A103; Dako Cytomation, Hamburg, Germany) were detected with the additional use of secondary antibodies [Cy5-coupled $\mathrm{F}\left(\mathrm{ab}^{\prime}\right)_{2}$-antibody (Dianova, Hamburg, Germany) and biotinylated $\mathrm{F}\left(\mathrm{ab} \mathrm{b}_{2}\right.$-antibody (Becton Dickinson)] and streptavidin-PE (Dianova). FITC-dextran from Sigma-Aldrich (Deisenhofen, Germany) and CCL19 from R\&D Systems (Wiesbaden, Germany) were used. IL-1 $\beta$, IL-4, IL- 6 and TNF- $\alpha$ were purchased from R\&D Systems, IL-2 from Chiron Behring (Marburg, Germany), GM-CSF (Leukine ${ }^{\circ}$ ) from Berlex (Seattle, USA) and $\mathrm{PGE}_{2}$ from Sigma-Aldrich.

\section{Tumor cell lines and CTL}

The melanoma cell lines Mel-93.04A12 (HLA-A2 ${ }^{+}$, Melan- $\mathrm{A}^{+}$; gift from P. Schrier, Department of Immunohematology, Leiden University Hospital, Leiden, the Netherlands), Mel A375 (HLA-A2 ${ }^{+}$, Melan-A ${ }^{-}$; CRL1619; ATCC) and SK-Mel-29 (HLA-A2 ${ }^{+}$; gift from T. Wölfel, Third Department of Medicine, Hematology and Oncology, Johannes Gutenberg University of Mainz, Mainz, Germany) were cultured in RPMI 1640 medium supplemented with $10 \%$ fetal calf serum, $2 \mathrm{mM}$ L-glutamine, $1 \mathrm{mM}$ sodium pyruvate and non-essential amino acids. AK-EBV-B cells (gift from T. Wölfel) were cultured in RPMI 1640, containing 10\% fetal calf serum. The HLA-A2-restricted, MART-1/Melan- $\mathrm{A}_{26-35}$ specific CTL A42 (gift from M. C. Panelli, National Institutes of Health, Bethesda, MD) were cultured in RPMI 1640 supplemented with 10\% human serum (Lonza, Walkersville, USA), $2 \mathrm{mM} \mathrm{L}$-glutamin, $1 \mathrm{mM}$ sodium pyruvate, $100 \mathrm{IU}$ penicillin/streptomycin, $0.5 \mu \mathrm{g} / \mathrm{ml}$ mycoplasma removal agent (MP Biomedicals, Eschwege, Germany) and $125 \mathrm{IU} / \mathrm{ml} \mathrm{IL}-2.5 \times 10^{5} \mathrm{CTL}$ were restimulated every two weeks using $1 \times 10^{5}$ SK-Mel 29 and $2 \times 10^{5}$ AK-EBV-B (both irradiated with $100 \mathrm{~Gy}$ ) in $1.5 \mathrm{ml} \mathrm{A} 42$ CTL medium per well of a 24-well plate. On the day of restimulation, $500 \mathrm{IU} / \mathrm{ml} \mathrm{IL-2}$ were added to the culture. A42 CTL were used for coculture experiments 8 days after restimulation.

\section{Generation and culture of 3d DC and 7d DC}

Monocytes were enriched from heparinized blood by Ficoll density gradient centrifugation and subsequent plate adherence or from a leukapheresis product via elutriation, as described previously [30]. For freezing of 
multiple aliquots, $2-4 \times 10^{7}$ monocytes per ampule were resuspended in VLE (very low endotoxin) RPMI supplemented with $5 \%$ human serum albumin $\left(20 \%\right.$ Octalbin $^{\circ}$, Octapharma, Langenfeld, Germany) and mixed 1:1 with freezing medium, containing VLE RPMI, 10\% human serum albumin and 20\% DMSO. After thawing, $15 \times$ $10^{6}$ monocytes were plated in a Nunclon ${ }^{\mathrm{Tw}} \mathrm{flask}\left(80 \mathrm{~cm}^{2}\right.$; Nunc, Wiesbaden, Germany) in VLE RPMI medium supplemented with $1.5 \%$ human serum. For inducing the development of $2 \mathrm{~d}$ iDC, $20 \mathrm{ng} / \mathrm{ml} \mathrm{IL-4}$ and $100 \mathrm{ng} /$ $\mathrm{ml}$ GM-CSF were added to the medium immediately after plating the monocytes. On day two, 2d iDC could be harvested for study. For maturation, the $2 \mathrm{~d}$ iDC were cultured with the four component cocktail, containing $10 \mathrm{ng} / \mathrm{ml} \mathrm{IL-1 \beta ,} 15 \mathrm{ng} / \mathrm{ml} \mathrm{IL-6,} 10 \mathrm{ng} / \mathrm{ml}$ TNF- $\alpha$ and $1000 \mathrm{ng} / \mathrm{ml} \mathrm{PGE}{ }_{2}$ in addition to $100 \mathrm{ng} / \mathrm{ml} \mathrm{GM-CSF}$ and $20 \mathrm{ng} / \mathrm{ml} \mathrm{IL}-4$ [22]. After $24 \mathrm{~h}$, the $3 \mathrm{~d} \mathrm{mDC}$ were harvested for study. To generate $7 \mathrm{~d} D C$, the culture medium was supplemented with $20 \mathrm{ng} / \mathrm{ml} \mathrm{IL-4}$ and 100 $\mathrm{ng} / \mathrm{ml} \mathrm{GM-CSF}$ on days 1 and 3 after plating the monocytes. On day 6 , the maturation cocktail (as for $3 \mathrm{~d}$ $\mathrm{mDC}$ ) was added to the culture of $6 \mathrm{~d} \mathrm{iDC}$ and $7 \mathrm{~d} \mathrm{mDC}$ where harvested for study after $24 \mathrm{~h}$. Prior to freezing, DC were resuspended in $20 \%$ human serum albumin and mixed with equal amounts of freezing medium, containing 20\% human serum albumin, 20\% DMSO and $10 \%$ glucose (Braun, Melsungen, Germany).

\section{Generation of MART-1/Melan-A ivtRNA}

The mMESSAGEmMACHINE ${ }^{\mathrm{rm}}$ Kit from Applied Biosystems (Darmstadt, Germany) was used for the production of MART-1/Melan-A ivtRNA. The linearized vector pcDNAI/Amp/Aa1 (gift from T. Wölfel), encoding the MART-1/Melan-A cDNA, served as a template for in vitro transcription. To increase the stability of the RNA, a poly-A tail was added to the ivtRNA with the aid of the Poly(A) Tailing Kit ${ }^{\mathrm{mm}}$ (Applied Biosystems). The kits were used according to the manufacturers' instructions.

\section{Cell surface staining of DC}

The expression of cell surface molecules on DC was detected using specific monoclonal antibodies [CD14 (clone M5E2), CD83 (clone HB15e), CD209 (clone DCN46), CD40 (clone 5C3), HLA-DR (clone G46-6), CCR7 (clone 2H4), CD86 (clone 2331), CD80 (clone L307.4) and CD274 (clone M1H1), all Becton Dickinson] and measured by flow cytometry. $5 \times 10^{4} \mathrm{DC}$ were washed with ice-cold PBS supplemented with $1 \%$ FCS and incubated for $30 \mathrm{~min}$ with the appropriate antibody (1:25 dilution). If the first antibody was directly linked to a fluorochrome, the cells were washed once again, as described above, and resuspended in $200 \mu \mathrm{l}$ PBS containing 1\% FCS. If use of a secondary antibody was necessary, the cells were washed and incubated with the secondary antibody for an additional $20 \mathrm{~min}$, washed again and resuspended as described above. The DC were analyzed using either FACS Calibur ${ }^{\mathrm{Tw}}$ or LSR-II ${ }^{\mathrm{Tw}}$ instruments (BD Biosciences, Heidelberg, Germany). Results were evaluated using the CellQuest ${ }^{\mathrm{tm}}(\mathrm{BD}$ Biosciences) or FloJo $^{\mathrm{mm}}$ (Tree Star, Inc., Ashland, OR) software.

\section{Intracellular staining of DC}

For the detection of intracellular MART-1/Melan-A protein, $3 \times 10^{5}$ DC were fixed in PBS containing $1 \%$ paraformaldehyde (PFA) for $30 \mathrm{~min}$ on ice. After fixation, cells were washed with ice-cold PBS containing $1 \%$ FCS and resuspended in $500 \mu \mathrm{l} 0.1 \%$ saponin in PBS (Sigma-Aldrich) to enable permeabilization of the cell membrane. The cells were centrifuged and the cell pellet subsequently resuspended in $0.25 \%$ saponin in PBS. The MART-1/Melan-A antibody was added to the cell suspension (dilution 1:20) and incubated for $1 \mathrm{~h}$ at room temperature. After incubation, the cells were washed twice in $0.1 \%$ saponin in PBS. Incubation with the secondary, Cy5-coupled antibody (dilution 1:100) was performed in $0.25 \%$ saponin in PBS for $30 \mathrm{~min}$ at room temperature. Before being resuspended in PBS with $1 \%$ FCS, the cells were washed in $0.1 \%$ saponin in PBS once again. The MART-1/Melan-A expression was analyzed by flow cytometry, as described for cell surface staining.

\section{Phagocytosis assay}

The phagocytosis capacity of DC was tested via uptake of FITC-dextran. $2 \times 10^{5}$ DC were resuspended in 400 $\mu \mathrm{l}$ VLE RPMI containing $1.5 \%$ human serum, supplemented with $10 \mu \mathrm{g} / \mathrm{ml}$ FITC-dextran for $1 \mathrm{~h}$ at $37^{\circ} \mathrm{C}$ and $5 \% \mathrm{CO}_{2}$. As controls, the same concentrations of DC were incubated in medium without FITC-dextran for $1 \mathrm{~h}$ at $37^{\circ} \mathrm{C}$ or in medium supplemented with $10 \mu \mathrm{g} /$ $\mathrm{ml}$ FITC-dextran for $1 \mathrm{~h}$ on ice. After incubation, the cells were washed 3-4 times with ice-cold PBS containing $1 \%$ human serum and $0.1 \% \mathrm{NaN}_{3}$. The cells were resuspended in PBS containing 1\% human serum and analyzed by flow cytometry.

\section{Peptide-loading of DC}

$3-4 \times 10^{6}$ DC were incubated with different concentrations of the long or short MART-1/Melan-A peptides in a six-well-plate in VLE RPMI with 1.5\% human serum. The incubation duration for the long peptide was $24 \mathrm{~h}$ and for the short peptide $2 \mathrm{~h}$ or $24 \mathrm{~h}$. After incubation the DC were washed to remove excess peptide.

\section{Electroporation of DC}

Electroporation of DC was performed with the Gene Pulser Xcell ${ }^{\mathrm{m}}$ from Biorad (München, Germany) in $0.4 \mathrm{~cm}$ electroporation cuvettes (Biorad). Prior to 
electroporation, DC were washed twice in ice-cold OptiMEM I medium (Invitrogen, Karlsruhe, Germany). 2-3 $\times 10^{6} \mathrm{DC}$ were resuspended in $200 \mu \mathrm{l}$ OptiMEM I, preincubated on ice for three min and mixed with the MART-1/Melan-A ivtRNA (or the long MART-1/ Melan-A peptide) in the electroporation cuvette. DC were pulsed with either $250 \mathrm{~V}, 150 \mu \mathrm{F}$ or $300 \mathrm{~V}, 300 \mu \mathrm{F}$ (exponential protocol). DC electroporated with $\mathrm{H}_{2} \mathrm{O}$ were used as controls. Directly after pulsing, the cells were transferred into a six-well-plate, containing VLE RPMI with $1.5 \%$ human serum, and incubated at $37^{\circ} \mathrm{C}$ and $5 \% \mathrm{CO}_{2}$ for $24 \mathrm{~h}$.

\section{Migration assay}

A standard migration assay [31] was performed to determine the migratory capacity of DC. $2 \times 10^{5}$ DC were resuspended in $100 \mu \mathrm{l}$ migration medium (RPMI 1640 supplemented with $1 \%$ human serum, $500 \mathrm{U} / \mathrm{ml} \mathrm{GM-}$ CSF and $250 \mathrm{U} / \mathrm{ml} \mathrm{IL-4)}$ and incubated in the upper chamber of a 24-trans-well-plate (Costar/Corning, USA) for $2 \mathrm{~h}$ at $37^{\circ} \mathrm{C}$ and $5 \% \mathrm{CO}_{2}$. To determine chemokinedirected migration, the lower chambers contained 600 $\mu \mathrm{l}$ migration medium supplemented with $100 \mathrm{ng} / \mathrm{ml}$ CCL19 (R\&D Systems). For detection of spontaneous migration and cell chemokinesis, the migration medium in the lower chamber either contained no CCL19 or CCL19 was present in both the upper and lower chambers. After $2 \mathrm{~h}$ of incubation the cells from the upper and lower chambers were harvested and cell counts determined with the aid of the CellTiter-Glo ${ }^{\circ}$ Luminescent Cell Viability Assay (Promega).

\section{Induction of antigen-specific $\mathrm{T}$ lymphocytes}

$3 \mathrm{~d}$ and $7 \mathrm{~d} \mathrm{mDC}$ were harvested and pulsed with $10 \mu \mathrm{g} /$ ml MART-1/Melan-A $26-35$ peptide (ELAGIGILTV) for $120 \mathrm{~min}$ at $37^{\circ} \mathrm{C}, 5 \% \mathrm{CO}_{2}$ in a humidified atmosphere. Cryopreserved autologous PBMC isolated from HLA-A2 ${ }^{+}$donors were cocultured with autologous, peptidepulsed mDC using $1 \times 10^{6} \mathrm{PBMC}$ and $1 \times 10^{5} \mathrm{mDC}$ in T cell medium (RPMI 1640, $12.5 \mathrm{mM}$ HEPES, $4 \mathrm{mM}$ L-glutamine, $100 \mathrm{U} / \mathrm{ml}$ penicillin and streptomycin, supplemented with $10 \%$ pooled human serum). After 7 days of coculture, recovered lymphocytes were restimulated using the same cryopreserved batch of peptide-pulsed $\mathrm{DC}$ for $24 \mathrm{~h}$, at which time supernatants were collected for determination of IFN- $\gamma$ content via a standard ELISA using the OptEIA ${ }^{\mathrm{m}} \mathrm{Human}$ IFN- $\gamma$ ELISA Kit from BD Biosciences (Heidelberg, Germany) according to the manufacturers' protocol.

\section{Restimulation of effector CTL}

A42 CTL were stimulated with tumor cells or antigenloaded DC at a ratio of $2 \times 10^{4} \mathrm{CTL}$ and $4 \times 10^{4}$ tumor cells/DC per 96-well in $200 \mu \mathrm{l}$ A42 CTL medium. The coculture was set up $24 \mathrm{~h}$ after peptide-loading or pulsing of the DC with ivtRNA, if not otherwise indicated. The stimulation period was $24 \mathrm{~h}$. Coculture supernatants were stored at $-80^{\circ} \mathrm{C}$ for later analyses. The IFN- $\gamma$ release of the stimulated A42 CTL was measured in the supernatant media by ELISA, as above.

\section{Results}

Morphology and FITC-dextran uptake of $3 \mathrm{~d} \mathrm{mDC}$ and $7 \mathrm{~d}$ $\mathrm{mDC}$

Immature and mature DC were generated in vitro using either elutriated monocytes or monocytes obtained via plate adherence of freshly isolated PBMC of healthy donors. In all experiments, the $4 \mathrm{C}$ described by Jonuleit and colleagues was used for DC maturation [22]. Standard $7 \mathrm{~d} \mathrm{mDC}$ were induced within one week, whereas $3 \mathrm{~d} \mathrm{mDC}$ were generated within 72 hours. The different DC types were analyzed via flow cytometry and light microscopy and compared in terms of size and morphology (Fig. 1A and $1 \mathrm{~B})$. It was noticeable that $3 \mathrm{~d} \mathrm{mDC}$ were much smaller and showed a lower granularity than $7 \mathrm{~d} \mathrm{mDC} .3 \mathrm{~d}$ $\mathrm{mDC}$ were similar in size to $2 \mathrm{~d}$ iDC, whereas $7 \mathrm{~d} \mathrm{mDC}$ were clearly larger than $6 \mathrm{~d}$ iDC (Fig. 1A and 1B). Furthermore, $3 \mathrm{~d} \mathrm{mDC}$ displayed a higher yield and viability compared to $7 \mathrm{~d} \mathrm{mDC}$ (Table 1). All four DC types displayed capacity for macropinocytosis, following incubation with $10 \mu \mathrm{g} / \mathrm{ml}$ FITC-dextran for $1 \mathrm{~h}$ at $37^{\circ} \mathrm{C}$. As controls, DC were incubated without FITC-dextran under the same conditions or with FITC-dextran for $1 \mathrm{~h}$ at $4^{\circ} \mathrm{C}$. Subsequently, FITC-dextran expression was analyzed by flow cytometry (Fig. 1C). As expected, $2 \mathrm{~d}$ iDC and $6 \mathrm{~d}$ iDC showed greater FITC-dextran uptake and $6 \mathrm{~d}$ iDC achieved a higher mean fluorescence intensity compared with $2 \mathrm{~d}$ iDC, although comparable percentages of positive cells were seen. A somewhat lower FITC-dextran uptake was usually detected in $3 \mathrm{~d} \mathrm{mDC}$ compared with $7 \mathrm{~d} \mathrm{mDC}$. Nevertheless, immature and mature DC from both protocols displayed capacity to take up particles (e.g. antigens) from their surroundings.

\section{Phenotype of immature and mature DC}

After 2, 3, 6 and 7 days, respectively, fast DC and standard DC were stained with monoclonal antibodies specific for cell surface molecules typically expressed on iDC and $\mathrm{mDC}$ and subsequently analyzed via flow cytometry. $2 \mathrm{~d}$ iDC and $6 \mathrm{~d}$ iDC displayed no CD83 and only very low expression of CD80, which is typical for iDC. Differences between $2 \mathrm{~d}$ iDC and $6 \mathrm{~d}$ iDC were seen in the expression pattern of CD14, CD209 (DC-SIGN), CD86 and CCR7 in various donors $(\mathrm{n}=3)$. $3 \mathrm{~d}$ and $7 \mathrm{~d} \mathrm{mDC}$ showed the expected mature phenotypes, with high expression of CD83 and no expression of CD14. Both also expressed high levels of costimulatory molecules, like CD80, CD86 and CD40, as well as other cell surface 


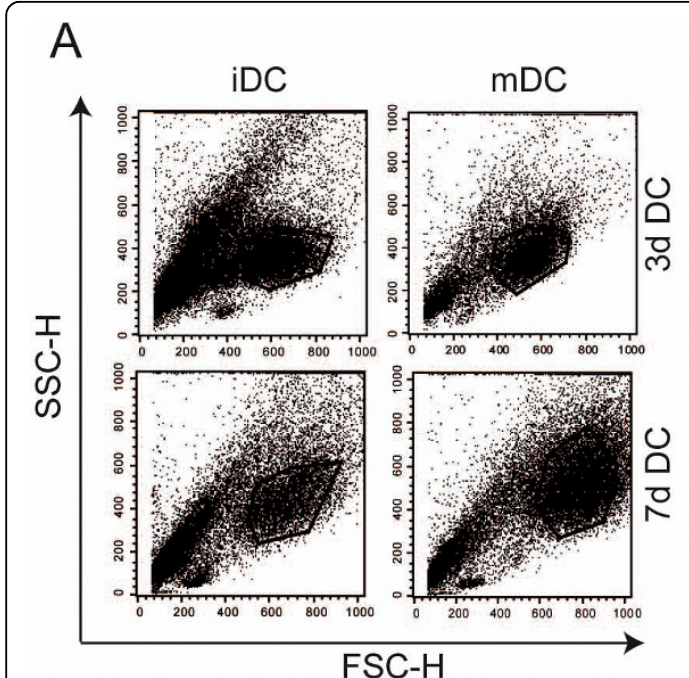

C

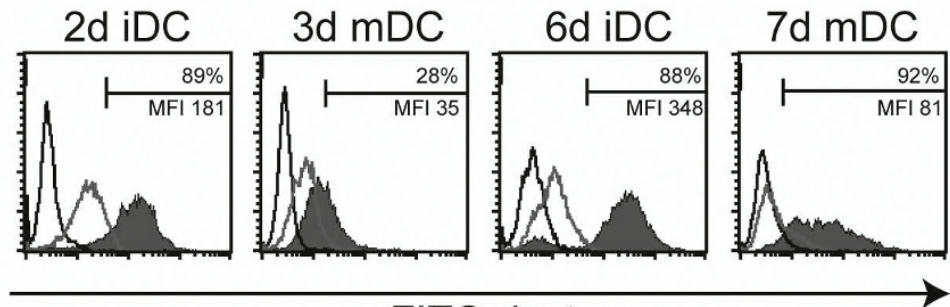

FITC-dextran
B
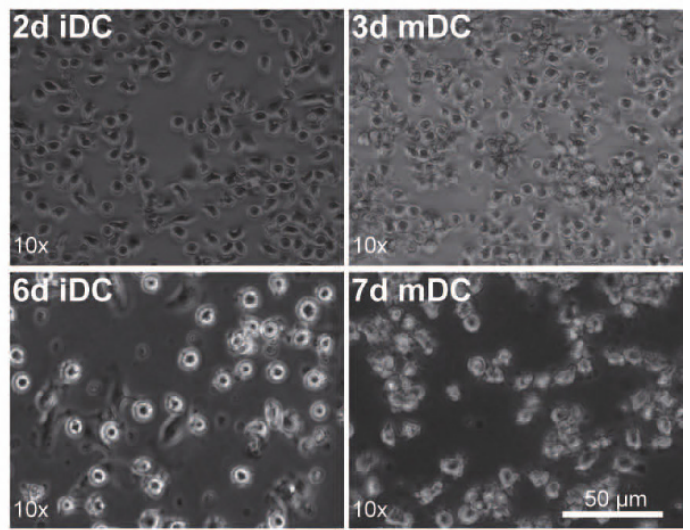

Figure 1 Morphology and FITC-dextran uptake of $\mathbf{3 d} \mathbf{~ m D C}$ and $\mathbf{7 d} \mathbf{~ m D C}$. The size and the morphology of immature and mature $3 \mathrm{~d}$ DC and $7 \mathrm{~d}$ DC were analyzed by (A) flow cytometry and (B) light microscopy. (C) DC were incubated without or with $10 \mu \mathrm{g} / \mathrm{ml} \mathrm{FITC-dextran} \mathrm{at} 37^{\circ} \mathrm{C}$ or at $4^{\circ} \mathrm{C}$ for 1 hour. The cells were then washed three times in ice-cold PBS with 1\% FCS. The uptake of FITC-dextran was analyzed by flow cytometry. Data are representative for three independent experiments. The left-most open histograms represent medium only controls, the open grey curves indicate $\mathrm{mDC}$ incubated with FITC-Dextran at $4^{\circ} \mathrm{C}$ and the filled histograms at $37^{\circ} \mathrm{C}$.

molecules that are important for the function of $\mathrm{mDC}$, including CD209 (DC-SIGN), HLA-DR and CCR7 (Fig. $2 \mathrm{~A}$ and $1 \mathrm{~B})$. Despite the shorter culture time, $3 \mathrm{~d} \mathrm{mDC}$ often expressed higher levels of CD209, CD40 and HLA-DR as compared to $7 \mathrm{~d} \mathrm{mDC}$. Whereas higher expression of these molecules on $3 \mathrm{~d} \mathrm{mDC}$ varied among different donors, HLA-DR was consistently seen to be better expressed on $3 \mathrm{~d} \mathrm{mDC}$ in different donors $(\mathrm{n}=3)$. In contrast, expression of the inhibitory molecule CD274 (B7-H1) was consistently lower on 3d than on $7 \mathrm{~d} \mathrm{mDC}$. This difference was even more striking when the expression of the positive costimulatory molecule CD80 and the inhibitory molecule CD274 was directly compared. Thus, $3 \mathrm{~d} \mathrm{mDC}$ displayed a stronger positive costimulatory phenotype, with higher expression of CD80 compared to CD274, whereas 7d mDC showed a lower level of CD80 compared to CD274 (Fig. 2C). Despite variability in levels of expression among different donors, these data may suggest that $3 \mathrm{~d} \mathrm{mDC}$ might have a slight advantage in the expression pattern of costimulatory molecules and thereby may display a higher stimulatory capacity for $\mathrm{T}$ cells compared to $7 \mathrm{~d}$ $\mathrm{mDC}$.

\section{Migratory capacity of $3 \mathrm{~d} \mathrm{mDC}$ and $7 \mathrm{~d} \mathrm{mDC}$}

One of the key features of DC, besides their ability to take up antigens in the periphery, is to migrate to the lymph nodes in order to present antigenic peptides to $\mathrm{T}$ cells. Both $3 \mathrm{~d}$ and $7 \mathrm{~d} \mathrm{mDC}$ showed a high expression of CCR7 (Fig. 2A), which is an important receptor for homing of DC to lymph nodes. To test migratory capacity, iDC and $\mathrm{mDC}$ were examined using a standard migration assay. DC were incubated in the upper chamber of a trans-well-plate at $37^{\circ} \mathrm{C}$ for $2 \mathrm{~h}$. The lower chambers contained migration medium, with or without the chemokine CCL19. As an additional control for cell chemokinesis, CCL19 was placed in both the upper and lower chambers. Since CCL19 is a specific ligand for the CCR7 receptor, migration of DC towards medium containing CCL19 reveals a directed migratory capacity, whereas migration towards medium alone or in the presence of chemokine in both chambers corresponds to 
Table 1 Yield, purity and viability of immature and mature DC

\begin{tabular}{|c|c|c|c|c|}
\hline & $2 d$ iDC & 6d iDC & $3 \mathrm{~d} \mathrm{mDC}$ & $7 \mathrm{~d} \mathrm{mDC}$ \\
\hline \multicolumn{5}{|l|}{ Donor 1} \\
\hline Yield* & n.d. $^{+}$ & n.d. ${ }^{+}$ & $8 \%$ & $4 \%$ \\
\hline Purity ${ }^{\#}$ & n.d. ${ }^{+}$ & n.d. ${ }^{+}$ & $39 \%$ & $34 \%$ \\
\hline Viability $\$$ & n.d. ${ }^{+}$ & n.d..$^{+}$ & $94 \%$ & $78 \%$ \\
\hline \multicolumn{5}{|l|}{ Donor $3^{\&}$} \\
\hline Yield* & $12 \%^{\S}$ & $6 \%{ }^{\S}$ & $18 \%$ & $9 \%$ \\
\hline Purity ${ }^{\#}$ & $57 \%$ & $58 \%$ & $60 \%$ & $70 \%$ \\
\hline Viability & $93 \%$ & $84 \%$ & $95 \%$ & $86 \%$ \\
\hline \multicolumn{5}{|l|}{ Donor $4^{\&}$} \\
\hline Yield* & n.d. ${ }^{+}$ & n.d. ${ }^{+}$ & $4 \%$ & $3 \%$ \\
\hline Purity ${ }^{\#}$ & $32 \%$ & $30 \%$ & $42 \%$ & $60 \%$ \\
\hline Viability ${ }^{\$}$ & $85 \%$ & $76 \%$ & $86 \%$ & $81 \%$ \\
\hline
\end{tabular}

* Yield: from PBMC with the starting population set at $100 \%$.

${ }^{+}$n.d.: not determined.

\# Purity: SSC/FSC

$\$$ Viability: propidium iodide (PI) stain.

${ }^{8}$ Donors 3 and 4 are identical with donors 3 and 4 in Table 2 and Table 3.

${ }^{\S}$ These values are lower compared to $3 \mathrm{~d}$ and $7 \mathrm{~d} \mathrm{mDC}$ due to cell loss from strong adherence of iDC.

spontaneous, undirected migratory capacity and a more random movement of the DC (Fig. 3). Neither 2d iDC, nor $6 \mathrm{~d}$ iDC showed an ability to migrate, even though some expression of CCR7 was detected on these immature DC (Fig. 2A). In contrast, 3d mDC showed a higher directed migration compared with spontaneous migration. Strikingly, $7 \mathrm{~d} \mathrm{mDC}$ showed reduced directed migration compared to $3 \mathrm{~d} \mathrm{mDC}$ in all five donors tested, although the CCR7 expression on $3 \mathrm{~d} \mathrm{mDC}$ and $7 \mathrm{~d} \mathrm{mDC}$ was nearly the same (Fig. 2A). However, the differences in the directed migratory capacity between $3 \mathrm{~d}$ and $7 \mathrm{~d} \mathrm{mDC}$ were not statistically significant.

MART-1/Melan-A peptide recognition on DC by A42 CTL Next, 3d and 7d mDC were tested for their stimulatory capacity of $\mathrm{CD}^{+}$effector $\mathrm{T}$ cells. Fast and standard $\mathrm{mDC}$ prepared from HLA-A $2^{+}$donors were loaded exogenously with short MART-1/Melan- $\mathrm{A}_{26-35}$ peptide (ELAGIGILTV) for $2 \mathrm{~h}$ or $24 \mathrm{~h}$. Because this peptide is only 10 amino acids long it can bind directly to HLAA2 molecules. The peptide-loaded DC were cocultured for another $24 \mathrm{~h}$ with the MART-1/Melan-A-specific effector CTL A42 which recognize the MART-1/Melan$\mathrm{A}_{26-35}$ peptide presented by HLA-A2 molecules. Activation of CTL A42 was measured by IFN- $\gamma$ release. The MART-1/Melan-A-negative melanoma cell line Mel A375 and the MART-1/Melan-A-positive melanoma cell line Mel-93.04A12 were used as controls (Fig. 4A). A42 CTL showed IFN- $\gamma$ release after stimulation with either
$3 \mathrm{~d}$ or $7 \mathrm{~d} \mathrm{mDC}$. The amount of IFN- $\gamma$ was higher in cocultures using DC that had an increased duration of peptide loading, indicating that $24 \mathrm{~h}$ of peptide loading provided DC with higher amounts of HLA-A2-peptide ligand, resulting in better stimulatory capacity. The $3 \mathrm{~d}$ $\mathrm{mDC}$ were comparable to $7 \mathrm{~d} \mathrm{mDC}$ in their capacity to restimulate effector CTL after exogenous peptide loading for $24 \mathrm{~h}$.

\section{Uptake of long MART-1/Melan-A peptide by $3 \mathrm{~d} \mathrm{mDC}$ and 7d mDC}

The ability of $3 \mathrm{~d}$ and $7 \mathrm{~d} \mathrm{mDC}$ to take up, process and present antigen was also tested. For this purpose, a long MART-1/Melan-A peptide, consisting of 23 amino acids, was used. This peptide is too long to be exogenously loaded directly onto HLA-A2 molecules. Therefore, it has to be processed by the DC, including cleavage by the proteasome and transport to the endoplasmic reticulum for binding on $\mathrm{MHC}$ and export to the cell surface, where it can be recognized by CTL. 3d and $7 \mathrm{~d} \mathrm{mDC}$ were incubated with different amounts of long peptide for $24 \mathrm{~h}$, washed and cocultured with A42 CTL for an additional $24 \mathrm{~h}$. IFN- $\gamma$ release by the CTL was measured via ELISA (Fig. 4B). Again, both mDC types showed capacity to stimulate CTL after incubation with the long peptide, revealing that adequate uptake of peptide occurred and both DC types were able to intracellularly process and present the correct epitope.

\section{Electroporation of $3 \mathrm{~d} \mathrm{mDC}$ and $7 \mathrm{~d} \mathrm{mDC}$ with peptide or ivtRNA}

To bypass the lower spontaneous uptake of antigen by $\mathrm{mDC}$, it is possible to use electroporation to introduce either peptide or $i v t$ RNA into DC. We compared $3 \mathrm{~d}$ and $7 \mathrm{~d} \mathrm{mDC}$ that were electroporated according to optimal parameters that were previously established for $7 \mathrm{~d}$ mDC [32]. After introduction of $1 \mu \mathrm{g}, 5 \mu \mathrm{g}$ or 10 $\mu \mathrm{g}$ of long peptide, the $\mathrm{mDC}$ were incubated at $37^{\circ} \mathrm{C}$ for $24 \mathrm{~h}$ and then cocultured with A42 CTL. Once again, $3 \mathrm{~d} \mathrm{mDC}$ showed capacity comparable to $7 \mathrm{~d}$ $\mathrm{mDC}$ for stimulation of IFN- $\gamma$ release by the CTL (Fig. 5A). Use of $i v t$ RNA is an attractive source of antigen that can be easily and cheaply generated from any antigen-encoding cDNA. To analyze this as a source of antigen, immature and mature $\mathrm{DC}$ were electroporated with $24 \mu \mathrm{g}$ of $i v t$ RNA encoding MART-1/Melan-A, using the same electroporation conditions as applied with the long peptide. After $24 \mathrm{~h}$ of incubation at $37^{\circ} \mathrm{C}$, the electroporated $\mathrm{DC}$ were cocultured with $\mathrm{A} 42$ CTL for another $24 \mathrm{~h}$. Whereas 2d iDC were unable to stimulate A42 CTL, 3d mDC showed a weak but detectable stimulatory capacity. In contrast, A42 CTL responded very well to stimulation with ivtRNAtransfected 7d mDC (Fig. 5B). 


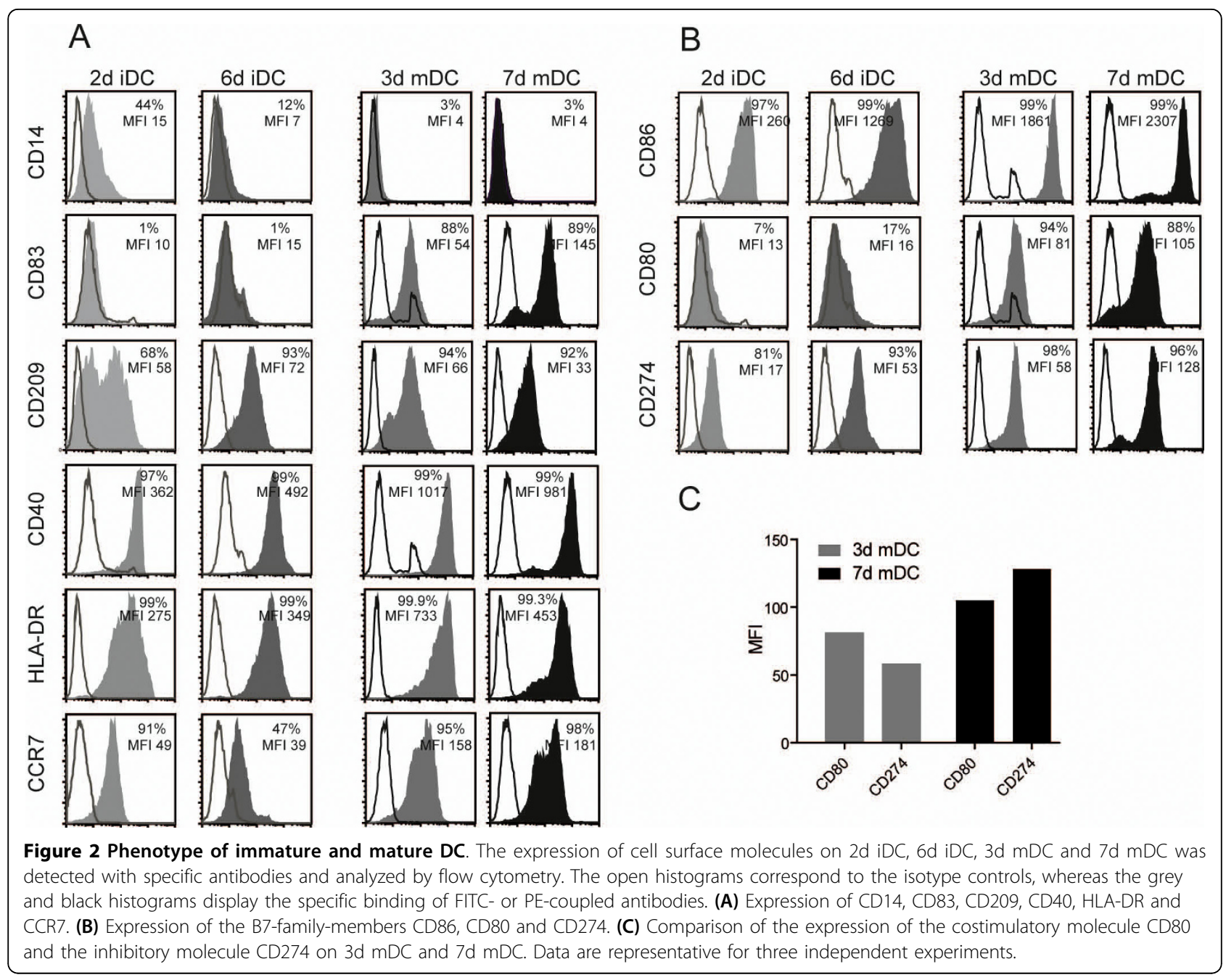

Since the electroporation conditions used in this experiment were originally established for $7 \mathrm{~d} \mathrm{mDC}$, it was possible that they might be suboptimal for $3 \mathrm{~d} \mathrm{mDC}$. It was seen, for example, that the stimulatory capacity of $3 \mathrm{~d} \mathrm{mDC}$ could be improved by using higher amounts of ivtRNA with these electroporation parameters (data not shown). This, however, was a poor solution for clinical application of $\mathrm{mDC}$ since it would increase costs for production of $i v t \mathrm{RNA}$. Therefore, alternate electroporation conditions for $3 \mathrm{~d} \mathrm{mDC}$ were explored in order to improve the efficiency of $i v t$ RNA transfer. After testing several variations of electroporation, modified parameters of $300 \mathrm{~V}$ and $300 \mu \mathrm{F}$ (exponential protocol) were found that facilitated optimal eGFP expression in 3d $\mathrm{mDC}$ after transfer of $i v t \mathrm{RNA}$ (data not shown).

Based on these observations, protein expression and stimulatory capacity were again compared in $3 \mathrm{~d}$ and $7 \mathrm{~d}$ $\mathrm{mDC}$ that were loaded with MART-1/Melan-A ivtRNA, applying both the old and modified parameters. Hereby, $3 \mathrm{~d}$ and $7 \mathrm{~d} \mathrm{mDC}$ were electroporated with $12 \mu \mathrm{g} i v t \mathrm{RNA}$, incubated for $24 \mathrm{~h}$ and then cocultured with A42 CTL for an additional $24 \mathrm{~h}$. Three hours after electroporation, the MART-1/Melan-A protein expression was assessed in $3 \mathrm{~d}$ and $7 \mathrm{~d} \mathrm{mDC}$ via intracellular staining using a MART-1/Melan-A-specific antibody and flow cytometry (Fig. 5C). With the modified parameters $(300 \mathrm{~V}, 300 \mu \mathrm{F}), 3 \mathrm{~d} \mathrm{mDC}$ showed a higher percentage of positive cells ( $88 \%$ vs. $79 \%$ ) and a nearly five-fold increase in MFI (361 vs. 74) compared with $3 \mathrm{~d} \mathrm{mDC}$ electroporated according to the older conditions. In contrast, the percentage of MART-1/Melan-A positive cells remained similar with only a slight increase in MFI (1.5-fold) in $7 \mathrm{~d} \mathrm{mDC}$. Under both conditions, $7 \mathrm{~d} \mathrm{mDC}$ displayed a poor recovery rate $24 \mathrm{~h}$ after electroporation, using either the old or modified parameters $(34 \%$ and $25 \%$, respectively) compared to $3 \mathrm{~d} \mathrm{mDC}$ ( $77 \%$ and $60 \%$, respectively). Furthermore, $3 \mathrm{~d} \mathrm{mDC}$ showed a higher viability after electroporation compared to $7 \mathrm{~d} \mathrm{mDC}$ (Table 2). The improved MART-1/Melan-A expression in $3 \mathrm{~d} \mathrm{mDC}$ correlated with a substantial increase in 


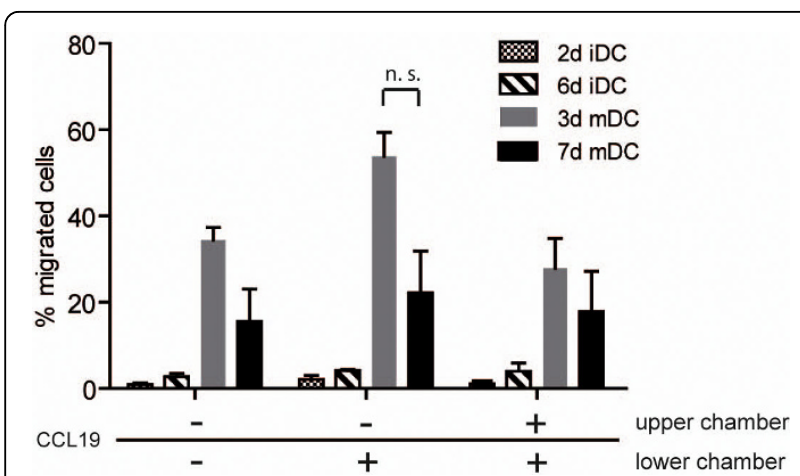

Figure 3 Migratory capacity of immature and mature DC. $2 d$ iDC, 6d iDC, 3d mDC and 7d $\mathrm{mDC}$ were compared for their migratory capacity towards migration medium containing (+) or lacking (-) CCL19 in a trans-well migration assay. To measure directed migration, the medium in the lower chamber of the transwell plate was supplied with $100 \mathrm{ng} / \mathrm{ml}$ CCL19, spontaneous migratory capacity was detected using medium that did not contain CCL19 in the lower chamber and random cell chemokinesis was determined by adding CCL19 to both the upper and the lower chambers. $2 \times 10^{5} \mathrm{DC}$ were added in the upper chamber and incubated at $37^{\circ} \mathrm{C}$ and $5 \% \mathrm{CO}_{2}$ for $2 \mathrm{~h}$. Afterwards, DC numbers in the lower chambers were determined. Shown are three independent donors as mean values with standard errors of the mean (SEM). Statistical analyses were performed using the Mann Whitney test (n.s.: not significant). stimulatory capacity (Fig. 5D). This was detected as a three-fold higher IFN- $\gamma$ release from A42 CTL. 7d mDC also showed a somewhat higher stimulatory capacity, corresponding to their higher level of protein expression.

\section{Recoveries of $3 \mathrm{~d} \mathrm{mDC}$ and $7 \mathrm{~d} \mathrm{mDC}$ after freezing and thawing}

For use in clinical application, it is important that large lots of antigen-loaded $\mathrm{mDC}$ can be prepared and cryopreserved in multiple aliquots for individual applications over time. To determine cell recovery after freezing and thawing, $3 \mathrm{~d}$ and $7 \mathrm{~d} \mathrm{mDC}$ were frozen, without or $3 \mathrm{~h}$ after electroporation. After several days of storage, the DC were thawed and cell recoveries were determined (Table 2). In the absence of electroporation, the recoveries of both $3 \mathrm{~d}$ and $7 \mathrm{~d} \mathrm{mDC}$ after cryopreservation and thawing were equal ( $68 \%$ vs. $70 \%$, respectively). In contrast, $3 \mathrm{~d} \mathrm{mDC}$ displayed a greater robustness after electroporation and cryopreservation, leading to substantially higher cell recoveries compared with $7 \mathrm{~d} \mathrm{mDC}(41 \%$ vs. $18 \%$ ) and to higher cell viabilities (Table 3).

\section{Stimulation of naïve T cells}

Since it is essential for DC-based vaccines to enable de novo priming of new $\mathrm{T}$ cell responses, we also
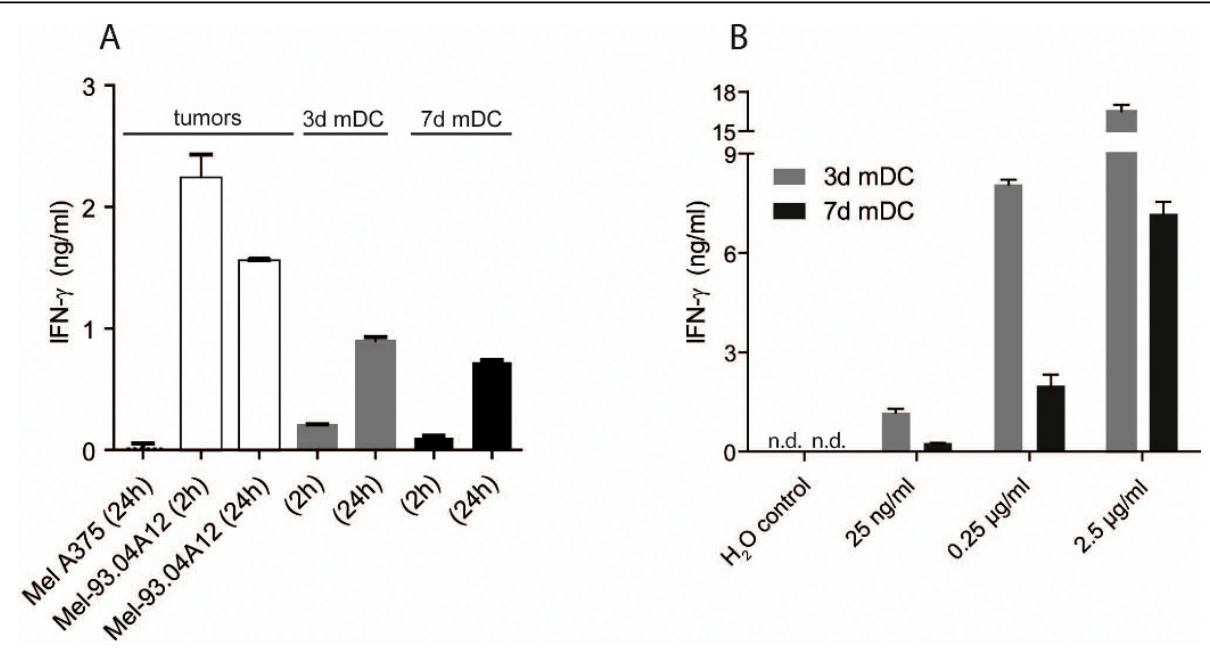

Figure 4 Recognition of MART-1/Melan-A peptide on $\mathbf{3 d} \mathrm{mDC}$ and $7 \mathrm{~d}$ mDC by MART-1/Melan-A-specific CTL. (A) $3 \mathrm{~d} m D C$ and $7 \mathrm{~d} m D C$ were exogenously loaded with $10 \mathrm{\mu g} / \mathrm{ml}$ short MART-1/Melan- $\mathrm{A}_{26-35}$ peptide for $2 \mathrm{~h}$ or $24 \mathrm{~h}$ at $37^{\circ} \mathrm{C}$ and $5 \% \mathrm{CO}_{2}$. After washing, the peptideloaded DC were cocultured with MART-1/Melan-A-specific A42 CTL for $24 \mathrm{~h}$ at $37^{\circ} \mathrm{C}$ and $5 \% \mathrm{CO}_{2}$. MART-1/Melan-A-positive tumor cells (Mel93.04A12) and MART-1/Melan-A-negative tumor cells (Mel A375) served as controls and were cocultured with A42 CTL at the same time points as the DC (2 $\mathrm{h}$ and $24 \mathrm{~h}$ ). The IFN- $\gamma$ release of A42 CTL was measured by IFN- $\gamma$-ELISA. The columns show mean values of triplicates with standard deviations. Data are representative for two experiments. (B) $3 \mathrm{~d} \mathrm{mDC}$ and $7 \mathrm{~d} \mathrm{mDC}$ were incubated with different amounts of long MART-1/Melan-A peptide for $24 \mathrm{~h}$ at $37^{\circ} \mathrm{C}$ and $5 \% \mathrm{CO}_{2}$. The DC were cocultured with A42 CTL for additional $24 \mathrm{~h}$. The IFN- $\gamma$ release of A42 CTL was measured by IFN- $\gamma$-ELISA. The columns show mean values of duplicates with standard deviations. The data for $2.5 \mu \mathrm{g} / \mathrm{ml}$ are representative for two independent experiments (n.d.: not detected). 

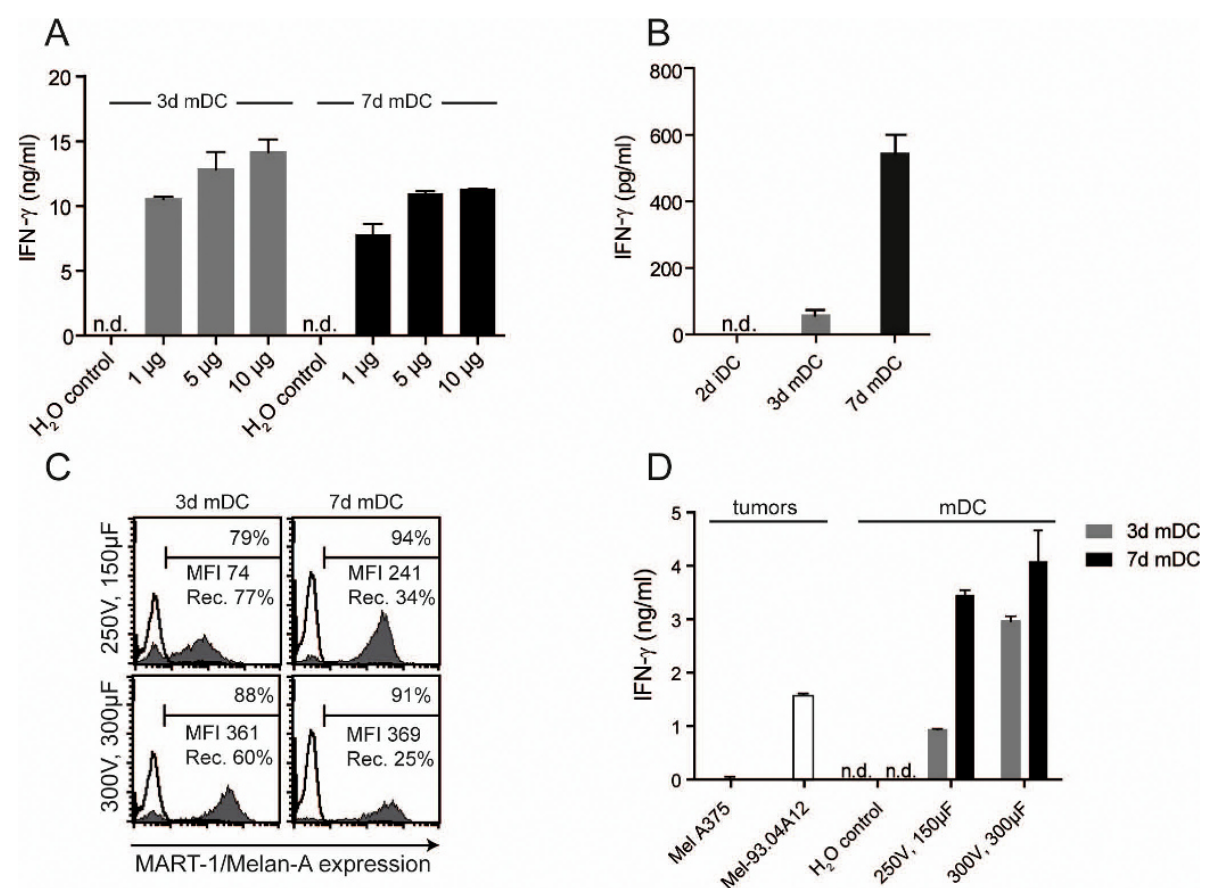

Figure 5 Electroporation of $3 \mathrm{~d}$ mDC and 7d mDC with long MART-1/Melan-A peptide and MART-1/Melan-A-encoding ivtRNA. (A) $3 \mathrm{~d}$ $\mathrm{mDC}$ and $7 \mathrm{~d} \mathrm{mDC}$ were electroporated $(250 \mathrm{~V}, 150 \mu \mathrm{F})$ with $1 \mu \mathrm{g}, 5 \mu \mathrm{g}$ and $10 \mu \mathrm{g}$ long MART-1/Melan-A peptide. After $24 \mathrm{~h}$ incubation at $37^{\circ} \mathrm{C}$ and $5 \% \mathrm{CO}_{2}$, the DC were cocultured with A42 CTL for $24 \mathrm{~h}$. (B) $2 \mathrm{~d}$ iDC, 3d mDC and 7d mDC were electroporated $(250 \mathrm{~V}, 150 \mu \mathrm{F})$ with $24 \mu \mathrm{g}$ MART-1/Melan-A ivtRNA, incubated at $37^{\circ} \mathrm{C}$ for $24 \mathrm{~h}$ and cocultured with $\mathrm{A} 42 \mathrm{CTL}$ for $24 \mathrm{~h}(\mathrm{n}=3)$. (C) $3 \mathrm{~d} \mathrm{mDC}$ and $7 \mathrm{~d}$ mDC were

electroporated with $12 \mu \mathrm{g}$ MART-1/Melan-A ivtRNA at different electroporation conditions ( $250 \mathrm{~V}, 150 \mu \mathrm{F}$ and $300 \mathrm{~V}, 300 \mu \mathrm{F}$ ), respectively. $3 \mathrm{~h}$ after electroporation, $\mathrm{mDC}$ were stained intracellularly with a MART-1/Melan-A-specific antibody and analyzed by flow cytometry $(n=2)$. (D) 24 $\mathrm{h}$ after electroporation with MART-1/Melan-A ivtRNA, DC were cocultured with A42 CTL for $24 \mathrm{~h}(\mathrm{n}=2)$. The IFN- $\gamma$ release of the A42 CTL was measured by IFN- $\gamma$-ELISA. The bars in A, B and D show mean values of triplicates with standard deviations (Rec.: recovery; n.d.: not detected).

Table 2 Viability after electroporation, cryopreservation and thawing

\begin{tabular}{|c|c|c|c|c|c|c|c|}
\hline & & \multicolumn{3}{|c|}{$3 \mathrm{~d} \mathrm{mDC}$} & \multicolumn{3}{|c|}{$7 \mathrm{~d} \mathrm{mDC}$} \\
\hline & & w/o EP & $300 \mathrm{~V} 300 \mu \mathrm{F}$ & $250 \mathrm{~V} 150 \mu \mathrm{F}$ & w/o EP & $300 \mathrm{~V} 300 \mu \mathrm{F}$ & $250 \mathrm{~V} 150 \mu \mathrm{F}$ \\
\hline \multirow[t]{6}{*}{ Donor 3} & Before freezing & & & & & & \\
\hline & Cell counts $\left(\times 10^{6}\right)$ & 1.4 & 0.5 & 0.8 & 0.7 & 0.5 & 0.4 \\
\hline & Viability* & $94 \%$ & $90 \%$ & $91 \%$ & $75 \%$ & $52 \%$ & $74 \%$ \\
\hline & After thawing & & & & & & \\
\hline & Cell counts $\left(\times 10^{6}\right)$ & 0.5 & 0.2 & 0.2 & 0.2 & 0.1 & 0.2 \\
\hline & Viability* & $86 \%$ & $79 \%$ & $78 \%$ & $51 \%$ & $26 \%$ & $55 \%$ \\
\hline \multirow[t]{6}{*}{ Donor 4} & Before freezing & & & & & & \\
\hline & Cell counts $\left(\times 10^{6}\right)$ & 1.1 & 1.4 & 1.3 & 0.7 & 0.7 & 0.6 \\
\hline & Viability* & $89 \%$ & $85 \%$ & $88 \%$ & $59 \%$ & $58 \%$ & $62 \%$ \\
\hline & After thawing & & & & & & \\
\hline & Cell counts $\left(\times 10^{6}\right)$ & 1.0 & 0.9 & 0.8 & 0.6 & 0.4 & 0.5 \\
\hline & Viability* & $90 \%$ & $90 \%$ & $89 \%$ & $86 \%$ & $79 \%$ & $84 \%$ \\
\hline
\end{tabular}

* Viability: PI stain. 
Table 3 Recoveries of $3 \mathrm{~d} \mathrm{mDC}$ and $7 \mathrm{~d}$ mDC after cryopreservation and thawing

\begin{tabular}{|c|c|c|c|c|c|c|c|c|}
\hline & \multicolumn{2}{|c|}{$3 d \mathrm{mDC}-\mathrm{EP} *$} & \multicolumn{2}{|c|}{ 7d mDC - EP* } & \multicolumn{2}{|c|}{$3 d \mathrm{mDC}+E P^{*}$} & \multicolumn{2}{|c|}{$7 d \mathrm{mDC}+\mathrm{EP}^{*}$} \\
\hline & $\begin{array}{l}\text { counts } \\
\left(\times 10^{6}\right)\end{array}$ & $\%$ & $\begin{array}{l}\text { counts } \\
\left(\times 10^{6}\right)\end{array}$ & $\%$ & $\begin{array}{l}\text { counts } \\
\left(\times 10^{6}\right)\end{array}$ & $\%$ & $\begin{array}{l}\text { counts } \\
\left(\times 10^{6}\right)\end{array}$ & $\%$ \\
\hline \multicolumn{9}{|l|}{ Donor 1} \\
\hline Before EP* & & & & & 2.0 & 100 & 2.0 & 100 \\
\hline Before freezing & 1.6 & 100 & 1.2 & 100 & 1.4 & 70 & 1.3 & 65 \\
\hline After thawing & 0.9 & 59 & 0.9 & 73 & 0.9 & 43 & 0.5 & 26 \\
\hline \multicolumn{9}{|l|}{ Donor 2} \\
\hline Before EP* & & & & & 1.5 & 100 & 1.5 & 100 \\
\hline Before freezing & 1.2 & 100 & 0.5 & 100 & 1.0 & 65 & 0.3 & 23 \\
\hline After thawing & 1.0 & 83 & 0.5 & 98 & 0.7 & 47 & 0.3 & 17 \\
\hline \multicolumn{9}{|l|}{ Donor 3} \\
\hline Before EP* & & & & & 2.0 & 100 & 2.0 & 100 \\
\hline Before freezing & 1.4 & 100 & 0.7 & 100 & 0.5 & 25 & 0.5 & 25 \\
\hline After thawing & 0.5 & 37 & 0.2 & 23 & 0.2 & 11 & 0.1 & 3 \\
\hline \multicolumn{9}{|l|}{ Donor 4} \\
\hline Before EP* & & & & & 1.5 & 100 & 1.5 & 100 \\
\hline Before freezing & 1.1 & 100 & 0.7 & 100 & 1.4 & 93 & 0.7 & 45 \\
\hline After thawing & 1.0 & 91 & 0.6 & 86 & 0.9 & 61 & 0.4 & 27 \\
\hline mean $\%$ after thawing $\pm S^{+}$ & & $68 \pm 24$ & & $70 \pm 33$ & & $41 \pm 21$ & & $18 \pm 11$ \\
\hline
\end{tabular}

* EP: electroporation.

+ SD: standard deviation.

analyzed the capacities of MART-1/Melan-A peptideloaded $3 \mathrm{~d}$ and $7 \mathrm{~d} \mathrm{mDC}$ to stimulate naïve $\mathrm{T}$ cells in autologous cocultures. PBL were primed for seven days using either MART-1/Melan-A peptide-loaded 3d or 7d $\mathrm{mDC}$. At this time the primed cells were recovered and restimulated with either melanoma tumor cell lines or with the same batches of peptide-pulsed $3 \mathrm{~d}$ and $7 \mathrm{~d}$ $\mathrm{mDC}$ that were cryopreserved and thawed before use as stimulating cells. The levels of IFN- $\gamma$ secretion were detected by standard ELISA. When the primed $\mathrm{T}$ cells were restimulated with MART-1/Melan-A-expressing tumor cells they showed low levels of cytokine release which increased substantially upon restimulation with MART-1/Melan-A peptide-pulsed 3d mDC (Fig. 6). In contrast, the IFN- $\gamma$ secretion of PBL stimulated with MART-1/Melan-A peptide-pulsed 7d mDC was much weaker. As described previously for DC that were matured with $4 \mathrm{C}$ cocktail, we did not detect any IL12 p70 secretion after stimulation of DC using CD40ligand expressing cells from either $3 \mathrm{~d}$ or $7 \mathrm{~d} \mathrm{mDC}$ (data not shown).

\section{Discussion}

Since several different protocols for the generation of $\mathrm{mDC}$ using monocytes have been described to date, the aim of our study was to compare standard $7 \mathrm{~d}$ mDC with $3 \mathrm{~d} \mathrm{mDC}$ in terms of phenotype, processing and presentation of antigen after transfection of either peptide or ivtRNA and stimulation of effector CTL. If 3d $\mathrm{mDC}$ display the same key characteristics as $7 \mathrm{~d} \mathrm{mDC}$, they would be preferred for DC-vaccine development because of savings in time and costs.

In 2003, Dauer and colleagues published a protocol for the rapid generation of $\mathrm{mDC}$ in vitro $[25,26]$. These so called "fast DC" were induced from monocytes within 48 hours and showed typical phenotypic characteristics of $\mathrm{mDC}$. We modified this procedure somewhat by adding the $4 \mathrm{C}$ maturation cocktail, designed by Jonuleit and colleagues [22], to the cultures of immature DC on the second day, thereby yielding $\mathrm{mDC}$ after three days of culture.

First, we observed that $3 \mathrm{~d} \mathrm{mDC}$ retained a smaller size and lower granularity compared to $7 \mathrm{~d} \mathrm{mDC}$, as described for fast DC generated in $48 \mathrm{~h}[25,26,33]$. This difference in morphology raised the issue whether $3 \mathrm{~d}$ $\mathrm{mDC}$ would differ from $7 \mathrm{~d} \mathrm{mDC}$ in terms of antigen uptake, processing and presentation of antigen-derived peptides on the cell surface. Indeed, $3 \mathrm{~d} \mathrm{mDC}$ showed a lower capacity for spontaneous uptake of FITC-dextran from their surroundings, compared to $7 \mathrm{~d} \mathrm{mDC}$. The 


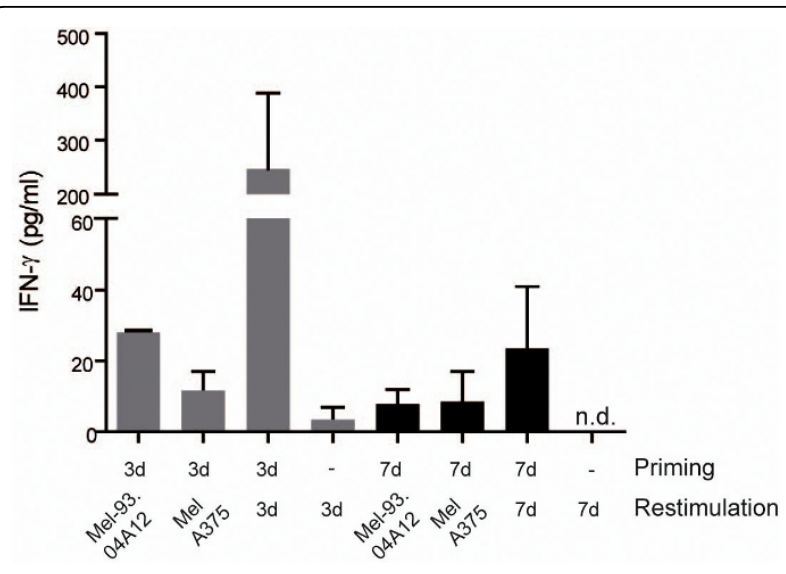

Figure 6 Stimulation of naïve T cells with MART-1/Melan-A peptide-pulsed $\mathbf{3 d}$ and $\mathbf{7 d} \mathbf{m D C}$. Autologous PBL were stimulated with MART-1/Melan-A peptide-pulsed 3d and $7 \mathrm{~d}$ mDC for 7 days, followed by specific restimulation for $24 \mathrm{~h}$ using peptide-pulsed $\mathrm{mDC}$ and Melan-A-positive tumor cells. The IFN- $\gamma$ release of the PBL was measured by IFN- $\gamma$-ELISA. Shown are two independent donors as mean values with SEM (n.d.: not detected).

phenotyping of $3 \mathrm{~d}$ and $7 \mathrm{~d} \mathrm{mDC}$ revealed that both types of $\mathrm{mDC}$ expressed comparable levels of many important surface molecules. Nevertheless, some differences were observed in the levels of costimulatory molecules that play an important role in interactions with $\mathrm{T}$ cells. Thus, differences in the intensity of expression of the inhibitory molecule CD274 were detected, which may impact on the costimulatory capacities of $3 \mathrm{~d}$ and $7 \mathrm{~d}$ $\mathrm{mDC}$ for T cells. CD274 (B7-H1, PD-L1) on DC interacts with PD-1 on $\mathrm{T}$ cells and transmits an inhibitory signal $[34,35]$. Therefore, DC that express a preponderance of CD274 might inhibit rather than foster $\mathrm{T}$ cell activation. We observed that $7 \mathrm{~d} \mathrm{mDC}$ expressed higher levels of CD274 compared to the costimulatory molecule CD80. In contrast, $3 \mathrm{~d} \mathrm{mDC}$ showed a reciprocal lower expression of CD274 compared to CD80 (Fig. 2). These results indicate that $3 \mathrm{~d} \mathrm{mDC}$ may be more effective in activating $\mathrm{T}$ cells compared to $7 \mathrm{~d} \mathrm{mDC}$, which would be advantageous for priming of naïve $\mathrm{T}$ cells. Nevertheless, when $3 \mathrm{~d}$ and $7 \mathrm{~d} \mathrm{mDC}$ were loaded exogenously with short MART-1/Melan-A peptide, both DC types showed comparable capacities to stimulate A42 CTL (Fig. 4A). These findings indicated that the higher ratio of CD274 to CD80 in $7 \mathrm{~d} \mathrm{mDC}$ did not impair their capacity to stimulate primed effector cells (Fig. 2B and 1C). While DC loading with short peptide led to comparable stimulation of CTL, $3 \mathrm{~d}$ and $7 \mathrm{~d} \mathrm{mDC}$ revealed different capacities to stimulate effector $\mathrm{T}$ cells after incubation with long peptide. IFN $-\gamma$ release from $\mathrm{T}$ cells after stimulation with standard $\mathrm{mDC}$ loaded with long peptide was previously noted to be much higher than stimulation with standard $\mathrm{mDC}$ loaded with short peptide [36]. This may be due to maintenance of a persisting pool of long peptide within the DC that could be processed and presented for a longer period after uptake. In our studies $3 \mathrm{~d} \mathrm{mDC}$ showed equal or better stimulatory capacity for $\mathrm{T}$ cells after incubation with long peptide compared to $7 \mathrm{~d} \mathrm{mDC}$, indicating that processing may have been more efficient in $3 \mathrm{~d} \mathrm{mDC}$, since the spontaneous uptake of exogenous material was lower in $3 \mathrm{~d} \mathrm{mDC}$, as evidenced by FITC-dextran uptake. After introduction of the long peptide by electroporation, comparable stimulatory capacities were found between $3 \mathrm{~d}$ and $7 \mathrm{~d} \mathrm{mDC}$. Since levels of IFN $-\gamma$ release by $\mathrm{T}$ cells were in general lower after stimulation with DC that were electroporated with peptide compared with spontaneous peptide uptake, we speculate that electroporation might diminish somewhat the antigen processing capacity of the DC.

Next, we analyzed protein expression in $3 d$ and $7 d$ $\mathrm{mDC}$ after electroporation of ivtRNA, alongside their stimulatory capacity for CTL. As shown previously, antigen-loaded fast $\mathrm{DC}$ were clearly able to stimulate $\mathrm{T}$ cells $[25,27]$. However, we extended these observations by comparing the stimulatory capacities of $3 \mathrm{~d}$ and $7 \mathrm{~d} \mathrm{mDC}$ side-by-side after electroporation of MART-1/Melan-A ivtRNA. Using previously established electroporation conditions, we noted that $3 \mathrm{~d} \mathrm{mDC}$ showed diminished stimulatory capacity compared to $7 \mathrm{~d} \mathrm{mDC}$ in repeated experiments with multiple donors. This was likely due to lower protein expression in $3 \mathrm{~d} \mathrm{mDC}$ after introduction of $i v t$ RNA. The low protein expression in $3 \mathrm{~d} \mathrm{mDC}$ could be overcome by using greater amounts of $i v t$ RNA (data not shown). However, based on the differences in morphology and size, we speculated that the more compact $3 \mathrm{~d}$ $\mathrm{mDC}$ might be more robust and that more intense electroporation conditions might improve ivtRNA transfer, yielding better protein expression after transfer of lower amounts of $i v t$ RNA. Indeed, alteration of the electroporation parameters yielded an improved protein expression in $3 \mathrm{~d} \mathrm{mDC}$, which subsequently showed a much better stimulatory capacity for CTL. Thus, once $3 \mathrm{~d}$ and $7 \mathrm{~d}$ mDC expressed comparable levels of protein, they showed comparable stimulatory capacities for CTL.

When testing the migratory capacities of immature and mature $3 \mathrm{~d}$ or $7 \mathrm{~d} \mathrm{DC}$, we observed that immature DC displayed neither spontaneous nor chemokinedirected migration. This was also found by Dauer and colleagues for immature DC prepared in $24 \mathrm{~h}$ from monocytes [37]. $3 \mathrm{~d} \mathrm{mDC}$ appeared to have somewhat better migratory capacity than $7 \mathrm{~d} \mathrm{mDC}$ in multiple donors, which might be related to a less terminallydifferentiated status. Since effective migration of DC is essential for the priming of naïve $T$ cells in the lymph nodes, this characteristic supports use of $3 \mathrm{~d} \mathrm{mDC}$ for vaccine development. 
Because $3 \mathrm{~d} \mathrm{mDC}$ were smaller than $7 \mathrm{~d} \mathrm{mDC}$ and seemed more resistant to electroporation, we speculated that they were more robust cells. Indeed, $3 \mathrm{~d} \mathrm{mDC}$ loading of $i v t$ RNA required a stronger electroporation pulse to achieve similar protein expression to $7 \mathrm{~d} \mathrm{mDC}$. Likewise, when recoveries of $3 \mathrm{~d} \mathrm{mDC}$ and $7 \mathrm{~d} \mathrm{mDC}$ were examined after cryopreservation and thawing, $3 \mathrm{~d} \mathrm{mDC}$ showed higher cell recoveries when the $\mathrm{mDC}$ were electroporated prior to cryopreservation. Furthermore, 3d $\mathrm{mDC}$ displayed higher cell viabilities after electroporation and cryopreservation when compared to $7 \mathrm{~d} \mathrm{mDC}$. Thus, 3d mDC yielded higher cell recoveries and thereby would be superior to $7 \mathrm{~d} \mathrm{mDC}$ for clinical application if a DC vaccine strategy entails electroporation with antigenic proteins or antigen-encoding ivtRNA, followed by cryopreservation of multiple aliquots for thawing and immediate application to patients.

Since it is important that $\mathrm{mDC}$ are able to stimulate naïve $T$ cells in a vaccine setting, we analyzed the stimulatory potential of MART-1/Melan-A peptide-pulsed 3d and $7 \mathrm{~d} \mathrm{mDC}$ on autologous PBL. Under short-term priming conditions of only seven days, we failed to detect any tumor-specific killing of MART-1/Melan-Aexpressing tumor cells nor did we detect enrichment of MART-1/Melan-A-multimer-positive T cells (data not shown). Nevertheless, PBL stimulated with peptidepulsed $3 \mathrm{~d}$ mDC showed a higher IFN- $\gamma$ release when restimulated with peptide-loaded $3 \mathrm{~d} \mathrm{mDC}$ compared to PBL that were primed and restimulated with $7 \mathrm{~d} \mathrm{mDC}$. It has been shown previously by others, that fast DC generated in $48 \mathrm{~h}$ had an equal or greater capacity to stimulate naïve $\mathrm{T}$ cells compared to $7 \mathrm{~d} \mathrm{mDC}[28,33]$. The failure to detect cytotoxic activity and detectable numbers of MART-1/Melan-A-multimer-positive T cells in our experiments is likely related to the use of $4 \mathrm{C}$ cocktail for DC maturation and the absence of IL-2 or IL-7 in the culture medium. It has already been described that DC matured with $4 \mathrm{C}$ cocktail do not produce bioactive IL-12p70, which is important for optimal polarization of naïve $\mathrm{T}$ cells for tumor recognition $[30,38]$. Improved stimulatory capacity of naïve $\mathrm{T}$ cells is achieved if $\mathrm{mDC}$ are generated using a cocktail that enables their production of IL-12p70. Recently, we showed indeed that $3 \mathrm{~d} \mathrm{mDC}$, matured with TLR-ligand containing maturation cocktails display a much higher stimulatory capacity for naïve $\mathrm{T}$ cells than $3 \mathrm{~d} \mathrm{mDC}$ matured with 4C cocktail [38].

\section{Conclusions}

Here we show that $3 \mathrm{~d} \mathrm{mDC}$ displayed similar characteristics to $7 \mathrm{~d} \mathrm{mDC}$ concerning phenotype and capacity to stimulate CTL after exogenous pulsing with short peptide. We observed that $3 \mathrm{~d} \mathrm{mDC}$ also had good capacities to stimulate CTL after uptake and processing of long peptide and they displayed a strong chemokine-directed migration. The $3 \mathrm{~d} \mathrm{mDC}$ were more robust and thereby required altered conditions for introduction of RNAencoding antigen via electroporation, however this characteristic likely accounts for higher cell recoveries after electroporation and cryopreservation compared to $7 \mathrm{~d}$ $\mathrm{mDC}$. Thus, $3 \mathrm{~d} \mathrm{mDC}$ offer a suitable alternative to $7 \mathrm{~d}$ $\mathrm{mDC}$ for use in clinical trials, thereby saving time and costs for cell production.

\section{Abbreviations}

CCR: chemokine receptor (C-C type); CD: cluster of differentiation; CTL: cytotoxic T lymphocyte(s); DC: dendritic cell(s); EGFP: enhanced green fluorescent protein; FACS: fluorescence activated cell sorting; FCS: fetal calf serum; GM-CSF: granulocyte macrophage-colony stimulating factor; IDC: immature dendritic cell(s); IFN: interferon; IL: interleukin; IVT(RNA): in vitro transcribed RNA; MDC: mature dendritic cell(s); MHC: major histocompatibility complex; PBS: phosphate buffered saline; $\mathrm{PGE}_{2}$ : prostaglandin $\mathrm{E}_{2}$; poly (I:C): polyriboinosinic polyribocytidylic acid; TGF: transforming growth factor; TNF: tumor necrosis factor; VLE: very low endotoxin.

\section{Declaration of competing interests}

The authors declare that they have no competing interests.

\section{Authors' contributions}

$\mathrm{MB}$ designed and performed the experiments and drafted the manuscript. SS and SW contributed to the initial development of 3d DC and provided scientific and technical advice. BF provided scientific advice and helped drafting the manuscript. DJS provided scientific advice, discussions of data and revised the manuscript. CG provided scientific advice, discussions of data and helped in the design of experiments. All authors read and approved the final manuscript.

\section{Acknowledgements}

The authors thank I. Bigalke and S. Tippmer (GMP Working Group, Helmholtz Zentrum München, Marchioninistr. 25, 81377 München, Germany) for supplying elutriated monocytes and technical advice concerning migration experiments, S. Eichenlaub and S. Kresse for excellent technical support. This work was supported by the German Research Foundation (SFB-TR36 and SFB-455), the Helmholtz Society Alliance "Immunotherapy of Cancer" (HA 202) and the BaylmmuNet program.

Received: 12 February 2010 Accepted: 28 September 2010

Published: 28 September 2010

\section{References}

1. Dallal RM, Lotze MT: The dendritic cell and human cancer vaccines. Curr Opin Immunol 2000, 12:583-588.

2. Banchereau J, Schuler-Thurner B, Palucka AK, Schuler G: Dendritic cells as vectors for therapy. Cell 2001, 106:271-274.

3. Gilboa E: DC-based cancer vaccines. J Clin Invest 2007, 117:1195-1203.

4. Mocellin S, Mandruzzato S, Bronte V, Lise M, Nitti D: Part I: Vaccines for solid tumours. Lancet Oncol 2004, 5:681-689.

5. Palucka K, Ueno H, Fay J, Banchereau J: Harnessing dendritic cells to generate cancer vaccines. Ann N Y Acad Sci 2009, 1174:88-98.

6. Banchereau J, Steinman RM: Dendritic cells and the control of immunity. Nature 1998, 392:245-252.

7. Mellman I, Steinman RM: Dendritic cells: specialized and regulated antigen processing machines. Cell 2001, 106:255-258.

8. Steinman RM, Hawiger D, Nussenzweig MC: Tolerogenic dendritic cells. Annu Rev Immunol 2003, 21:685-711.

9. Jonuleit H, Schmitt E, Schuler G, Knop J, Enk AH: Induction of interleukin 10-producing, nonproliferating $\mathrm{CD} 4(+) \mathrm{T}$ cells with regulatory properties by repetitive stimulation with allogeneic immature human dendritic cells. J Exp Med 2000, 192:1213-1222. 
10. Fong L, Engleman EG: Dendritic cells in cancer immunotherapy. Annu Rev Immunol 2000, 18:245-273.

11. Martin-Fontecha A, Lanzavecchia A, Sallusto F: Dendritic cell migration to peripheral lymph nodes. Handb Exp Pharmacol 2009, 31-49.

12. Schuler G, Schuler-Thurner B, Steinman RM: The use of dendritic cells in cancer immunotherapy. Curr Opin Immunol 2003, 15:138-147.

13. Sallusto F, Lanzavecchia A: Efficient presentation of soluble antigen by cultured human dendritic cells is maintained by granulocyte/ macrophage colony-stimulating factor plus interleukin 4 and downregulated by tumor necrosis factor alpha. J Exp Med 1994, 179:1109-1118

14. Sallusto F, Cella M, Danieli C, Lanzavecchia A: Dendritic cells use macropinocytosis and the mannose receptor to concentrate macromolecules in the major histocompatibility complex class II compartment: downregulation by cytokines and bacterial products. J Exp Med 1995, 182:389-400.

15. Mohamadzadeh M, Berard F, Essert G, Chalouni C, Pulendran B, Davoust J, Bridges G, Palucka AK, Banchereau J: Interleukin 15 skews monocyte differentiation into dendritic cells with features of Langerhans cells. J Exp Med 2001, 194:1013-1020.

16. Dubsky P, Saito H, Leogier M, Dantin C, Connolly JE, Banchereau J, Palucka AK: IL-15-induced human DC efficiently prime melanoma-specific naive CD8+ T cells to differentiate into CTL. Eur J Immunol 2007, 37:1678-1690.

17. Anguille S, Smits EL, Cools N, Goossens H, Berneman ZN, Van Tendeloo VF: Short-term cultured, interleukin-15 differentiated dendritic cells have potent immunostimulatory properties. J Transl Med 2009, 7:109.

18. Breckpot K, Corthals J, Bonehill A, Michiels A, Tuyaerts S, Aerts C, Heirman C, Thielemans $\mathrm{K}$ : Dendritic cells differentiated in the presence of IFN-\{beta\} and IL-3 are potent inducers of an antigen-specific CD8+ T cell response. J Leukoc Biol 2005, 78:898-908.

19. Trakatelli M, Toungouz M, Blocklet D, Dodoo Y, Gordower L, Laporte M, Vereecken P, Sales F, Mortier L, Mazouz N, et al: A new dendritic cell vaccine generated with interleukin-3 and interferon-beta induces CD8+ $\mathrm{T}$ cell responses against NA17-A2 tumor peptide in melanoma patients. Cancer Immunol Immunother 2006, 55:469-474.

20. Han TH, Jin P, Ren J, Slezak S, Marincola FM, Stroncek DF: Evaluation of 3 clinical dendritic cell maturation protocols containing lipopolysaccharide and interferon-gamma. J Immunother 2009, 32:399-407.

21. Riva S, Nolli ML, Lutz MB, Citterio S, Girolomoni G, Winzler C, RicciardiCastagnoli P: Bacteria and bacterial cell wall constituents induce the production of regulatory cytokines in dendritic cell clones. $J$ Inflamm 1996, 46:98-105.

22. Jonuleit H, Kuhn U, Muller G, Steinbrink K, Paragnik L, Schmitt E, Knop J, Enk AH: Pro-inflammatory cytokines and prostaglandins induce maturation of potent immunostimulatory dendritic cells under fetal calf serum-free conditions. Eur J Immunol 1997, 27:3135-3142.

23. Bonehill A, Tuyaerts S, Van Nuffel AM, Heirman C, Bos TJ, Fostier K, Neyns B, Thielemans $\mathrm{K}$ : Enhancing the T-cell stimulatory capacity of human dendritic cells by co-electroporation with CD40L, CD70 and constitutively active TLR4 encoding mRNA. Mol Ther 2008, 16:1170-1180.

24. Chen $\mathrm{CH}, \mathrm{Wu}$ TC: Experimental vaccine strategies for cancer immunotherapy. J Biomed Sci 1998, 5:231-252.

25. Dauer M, Obermaier B, Herten J, Haerle C, Pohl K, Rothenfusser $\mathrm{S}$, Schnurr M, Endres S, Eigler A: Mature dendritic cells derived from human monocytes within 48 hours: a novel strategy for dendritic cell differentiation from blood precursors. J Immunol 2003, 170:4069-4076

26. Obermaier B, Dauer M, Herten J, Schad K, Endres S, Eigler A: Development of a new protocol for 2-day generation of mature dendritic cells from human monocytes. Biol Proced Online 2003, 5:197-203.

27. Jarnjak-Jankovic S, Hammerstad H, Saeboe-Larssen S, Kvalheim G, Gaudernack G: A full scale comparative study of methods for generation of functional Dendritic cells for use as cancer vaccines. BMC Cancer 2007, 7:119

28. Dauer M, Schad K, Herten J, Junkmann J, Bauer C, Kiefl R, Endres S, Eigler A: FastDC derived from human monocytes within $48 \mathrm{~h}$ effectively prime tumor antigen-specific cytotoxic T cells. J Immunol Methods 2005, 302:145-155.

29. Randolph GJ, Beaulieu S, Lebecque S, Steinman RM, Muller WA: Differentiation of monocytes into dendritic cells in a model of transendothelial trafficking. Science 1998, 282:480-483.
30. Zobywalski A, Javorovic M, Frankenberger B, Pohla H, Kremmer E, Bigalke I, Schendel DJ: Generation of clinical grade dendritic cells with capacity to produce biologically active IL-12p70. J Transl Med 2007, 5:18.

31. Schaft N, Dorrie J, Thumann P, Beck VE, Muller I, Schultz ES, Kampgen E, Dieckmann D, Schuler G: Generation of an optimized polyvalent monocyte-derived dendritic cell vaccine by transfecting defined RNAs after rather than before maturation. J Immunol 2005, 174:3087-3097.

32. Javorovic M, Pohla H, Frankenberger B, Wolfel T, Schendel DJ: RNA transfer by electroporation into mature dendritic cells leading to reactivation of effector-memory cytotoxic T lymphocytes: a quantitative analysis. Mol Ther 2005, 12:734-743.

33. Ho WY, Nguyen HN, Wolfl M, Kuball J, Greenberg PD: In vitro methods for generating CD8+ T-cell clones for immunotherapy from the naive repertoire. J Immunol Methods 2006, 310:40-52.

34. Freeman GJ, Long AJ, Iwai Y, Bourque K, Chernova T, Nishimura H, Fitz LJ, Malenkovich N, Okazaki T, Byrne MC, et al: Engagement of the PD-1 immunoinhibitory receptor by a novel B7 family member leads to negative regulation of lymphocyte activation. J Exp Med 2000, 192:1027-1034.

35. Selenko-Gebauer N, Majdic O, Szekeres A, Hofler G, Guthann E, Korthauer U, Zlabinger $\mathrm{G}$, Steinberger P, Pickl WF, Stockinger $\mathrm{H}$, et al: B7-H1 (programmed death-1 ligand) on dendritic cells is involved in the induction and maintenance of T cell anergy. I Immunol 2003, 170:3637-3644

36. Faure F, Mantegazza A, Sadaka C, Sedlik C, Jotereau F, Amigorena S: Longlasting cross-presentation of tumor antigen in human DC. Eur J Immunol 2009, 39:380-390.

37. Dauer M, Schad K, Junkmann J, Bauer C, Herten J, Kiefl R, Schnurr M, Endres $\mathrm{S}$, Eigler A: IFN-alpha promotes definitive maturation of dendritic cells generated by short-term culture of monocytes with GM-CSF and IL4. J Leukoc Biol 2006, 80:278-286.

38. Spranger S, Javorovic M, Burdek M, Wilde S, Mosetter B, Tippmer S, Bigalke I, Geiger C, Schendel DJ, Frankenberger B: Generation of Th1Polarizing Dendritic Cells Using the TLR7/8 Agonist CL075. J Immunol 185:738-747

doi:10.1186/1479-5876-8-90

Cite this article as: Bürdek et al:: Three-day dendritic cells for vaccine development: Antigen uptake, processing and presentation. Journal of Translational Medicine 2010 8:90.

\section{Submit your next manuscript to BioMed Central and take full advantage of:}

- Convenient online submission

- Thorough peer review

- No space constraints or color figure charges

- Immediate publication on acceptance

- Inclusion in PubMed, CAS, Scopus and Google Scholar

- Research which is freely available for redistribution
C Biomed Central 